\title{
Evaluation of Knowledge about COVID-19 and Its Effect on Psychological States of University Students
}

\author{
Cihan Unal ${ }^{1}$, Ramazan Aslan ${ }^{2 *}$ Haci Omer Yilmaz ${ }^{3}$
}

\author{
${ }^{1}$ Department of Health Administration, Sakarya Business School, Sakarya University, TURKEY \\ ${ }^{2}$ Department of Emergency and Disaster Management, Faculty of Health Science, Gumushane University, TURKEY \\ ${ }^{3}$ Department of Nutrition and Dietetics, Faculty of Health Science, Gumushane University, TURKEY \\ *Corresponding Author: ramazan.att.aslan@gmail.com
}

Citation: Unal, C., Aslan, R. and Yilmaz, H. O. (2021). Evaluation of Knowledge about COVID-19 and Its Effect on Psychological States of University Students. European Journal of Environment and Public Health, 5(2), em0084. https://doi.org/10.21601/ejeph/11059

\section{ARTICLE INFO}

Received: 28 Jan. 2021

Accepted: 17 May 2021

\begin{abstract}
COVID-19 spread all over the world in a short time since the beginning of 2020, became a pandemic, caused serious interruptions and changes in peoples' daily life. University students were among the masses that experienced the most change in their lives. For this reason, in this study, it was aimed to assess the knowledge and psychological status of university students about COVID-19. This cross-sectional study was planned and data was collected by reaching the students with an online questionnaire. Within the scope of the study, data of 720 participants were analyzed. As a result of the study, it was determined that the level of knowledge of the participants about COVID-19 was high and the majority of the participants had a normal level of depression, anxiety and stress. This situation may be due to the participants' high level of knowledge about the disease, lowrisk perception, and living with parents. It has been determined that the sources from which students get information are effective on their knowledge levels and their knowledge levels on their DASS levels. The importance of directing students to the right sources to get information has been demonstrated.
\end{abstract}

Keywords: COVID-19, social media, university student, anxiety, depression

\section{INTRODUCTION}

Individuals follow communication channels for information that they do not know the meanings of events outside of their routine life or how to interpret them (BallRokeach and DeFleur, 1976). In this direction, thanks to today's technology, individuals receive various information about COVID-19 from various information sources. Due to the big effect of these technologies, it is especially important to get information from accurate and reliable sources. Today, individuals may get the right and false information about COVID-19 through traditional ways such as the social environment, specialists or non-specialists and technological channels such as web search, social media, television, etc. (Bergeron and Sanchez, 2005; Sallam et al., 2020).

Television is undoubtedly a communication tool that affects large audiences in obtaining and learning health information (Bergeron and Sanchez, 2005; Bulduklu, 2010; Sallam et al., 2020). In a study conducted in England, it has been determined that television is the most preferred informational source about COVID-19 (Ofcom, 2020).

With the increasing use of the internet in many countries, such as in Turkey, the internet started to replace television today. In a study conducted by the Turkish Statistical Institute (TURKSTAT), it was determined that approximately $70 \%$ of the Turkish people intended to use the internet was to get information about injury, disease and nutrition (TURKSTAT, 2019). With the internet becoming more accessible, social media has become a great place for people to comment and share their opinions, and for these reasons, it has become the main source of information for most people (Al-Motlaq, 2021). The use of social media has increased significantly with the pandemic (Ali et al., 2021). Especially young people are more exposed to and use social media tools more (Gao et al., 2020). While social media can be very useful for information, it should be used with caution due to some of its disadvantages (González-Padilla and Tortolero-Blanco, 2020; Venegas-Vera et al., 2020). In a study, it was found that fear-spreading posts about COVID-19 were shared many times on WeChat, a social media application (Xiang et al., 2020). In parallel with this study, some others found that social media can create fear, anxiety and stress by constantly spreading rumors and unconfirmed information (Boberg et al., 2020; Gao et al., 2020; Kumar and Nayar, 2021) The spread of these messages also can have devastating effects on public health (Islam et al., 2020).

Pandemic has a detrimental effect on the mental health of society by causing psychological crises (Hossain et al., 2020; 
Huang and Zhao, 2020; Xiang et al., 2020; Vindegaard and Benros, 2020). During the epidemic period, a wide range of individual, social, national and international psychological problems were observed. In individual terms, it is possible for them to feel fears such as illness, dying or social exclusion (Hall et al., 2008). Health crises, such as the COVID-19 pandemic, can trigger stress, anxiety and depression problems by causing psychological problems not only in healthcare professionals and positive patient groups but also in society (Liu et al., 2020; Zhang et al., 2020). Some studies indicate that the pandemic can affect the mental health of individuals at various levels of society, from infected patients and healthcare professionals to families, children and students (Bao et al., 2020; Chen et al., 2020; Ryu and Chun, 2020).

It has been found that the pandemic has many devastating effects on students' psychology (Ali et al., 2021; Drissi et al., 2020; Evans et al., 2021; Kecojevic et al., 2020; OdriozolaGonzález et al., 2020; Padrón et al., 2021). It is known that the disruptions in the academic activities of university students affect their psychology (Cao et al., 2020; Wang et al., 2020). Universities, after the decision taken by The Republic of Turkey's Higher Education Council (CoHE) in March 2020, was applied distance learning education instead of face-to-face in Turkey (CoHE, 2020). With this decision, the majority of the students went to their hometown, changed their lifestyle and started to live with their families. This situation could cause students to be psychologically affected by the virus.

Some studies indicated that students' DASS levels are affected by risk perception, level of knowledge, living with family, social isolation, etc. (Ardan et al., 2020; Bergeron and Sanchez, 2005; Cao et al., 2020; Husky et al., 2020; Kmietowicz, 2020; Sallam et al., 2020; Shigemura et al., 2020; Wong et al., 2004, 2007; Xiao, 2020). In many studies conducted on students, it has been determined that having a high level of knowledge about COVID-19 reduces the level of anxiety (Ardan et al., 2020; Bulduklu, 2010; Sallam et al., 2020; Shigemura et al., 2020; Wong et al., 2004).

In line with all these data, it is important to determine from which sources students obtain information about the pandemic, how these sources affect their knowledge level, and what kind of relationship is between their knowledge level and their psychological state. Because of this importance, the purpose of this study, designed at an early stage of the epidemic, was to determine students' level of COVID-19 knowledge, which media sources they use as a source of information about COVID-19 and psychological states. For this purpose, answers to the following research questions were sought.

1. Which sources of information did students choose to use to get information about COVID-19?

2. What are the reasons for students to choose information sources?

3. What is the level of knowledge of the students about COVID-19?

4. Do the levels of knowledge differ according to the source of information followed?

5. What are the DASS levels of the students?
6. Does the fact that someone they know has been diagnosed with COVID-19 causes a difference in DASS level?

7. Is there a relationship between COVID-19 knowledge level and DASS scores?

\section{MATERIALS AND METHODS}

\section{Study Design}

This study was designed as a cross-sectional model.

\section{Participants}

The convenience sample method was used in the study. The Faculty of Health Sciences was chosen as the study group. In this context, the study group consists of 2692 students studying in the spring semester of the 2019/2020 Academic Year in the 6 departments located in the Faculty of Health Sciences of Gümüşhane University. During the data collection process, it was tried to reach at least 30 participants from each department in the faculty and this goal has been achieved. The departments in the faculty are as follows:

- Emergency and Disaster Management (EDM)

- Nutrition and Dietetics (ND)

- $\operatorname{Nursing}(\mathrm{N})$

- Occupational Health and Safety (OHS)

- Healthcare Management (HM)

- Social Work (SW)

\section{Data Collection, Tools and Process}

The data were collected online between 05-06 April 2020. A questionnaire was used to collect data. The questionnaire used consists of two parts. In the first part, there were questions created by researchers to determine the ways of obtaining information about COVID-19 and knowledge levels about COVID-19.

Within the scope of demographic questions, the ages of the participants were asked as open-ended questions; the questions of gender, department and class were asked as multiple choice. The question to determine how often 10 sources (television, scientific articles, healthcare professional, acquaintances, web search, YouTube, Twitter, Instagram, Facebook, Telegram), were used, was asked in the Likert scale (never, sometimes, always). Participants were presented with reliable, quick information sharing, easy accessibility and mandatory options as the reason for following the sources, and they were asked to mark the appropriate ones. More than one reason could be marked in the reasons to follow the sources.

Having an acquaintance diagnosed with COVID-19 was asked in two options. The level of knowledge regarding the questions about COVID-19, which is frequently asked in society, was asked as a Likert scale (true, no information (NI) / unsure, wrong).

To determine the factors affecting the level of knowledge towards COVID-19, the marking for each thought was scored (false -1 , NI / unsure 0 and correct +1 ). By adding the points, a new score ranging from -17 to +17 was calculated. This shows that as the score increases, the level of knowledge increases. 
Table 1. Scoring of DASS-21

\begin{tabular}{cccc}
\hline & Depression & Anxiety & Stress \\
\hline Normal & $0-9$ & $0-7$ & $0-14$ \\
\hline Mild & $10-13$ & $8-9$ & $15-18$ \\
\hline Moderate & $14-20$ & $10-14$ & $19-25$ \\
\hline Severe & $21-27$ & $15-19$ & $26-33$ \\
\hline Extreme & $28+$ & $20+$ & $34+$ \\
\hline
\end{tabular}

Table 2. Demographic Characteristics of the Participants

\begin{tabular}{ccc}
\hline Group & n (720) & \% \\
\hline Gender & & \\
\hline Male & 144 & 20.0 \\
\hline Female & 576 & 80.0 \\
\hline Department & & 10.0 \\
\hline SW & 72 & 17.5 \\
\hline N & 126 & 34.6 \\
\hline HM & 249 & 15.8 \\
\hline EDM & 114 & 17.5 \\
\hline ND & 126 & 4.6 \\
\hline OHS & 33 & \\
\hline Grade & & 18.3 \\
\hline First & 132 & 26.3 \\
\hline Second & 189 & 26.6 \\
\hline Third & 206 &
\end{tabular}

According to the calculated score, 0 points and below are grouped as low level of knowledge, between 1 and 8 points grouped as medium level of knowledge and 9 and above grouped as high level of knowledge.

In the second part, there was the "Depression, Anxiety, Stress Scale (DASS-21)" which was developed by Brown et al. (1997) and was adapted to Turkish by Yılmaz et al. (2017). The scale consists of three dimensions: depression, anxiety and stress. In this study, Cronbach's alpha value of the scale was determined as .905 for depression, .839 for anxiety, .911 for stress, and .947 in total. Since the scale is a short form while scoring, the scores of the questions related to the dimensions were added and the dimension scores were calculated and the scores were multiplied by two. As a result, the levels represented by the scores obtained for each dimension of the scale are given in Table 1.

\section{Data Analysis}

SPSS 22 package program was used to analyze the data. Non-parametric tests were used because the data could not provide the assumption of normality. Percentage, frequency, median, minimum (min.), maximum (max.), mean rank (MR), sum of rank (SR) and Q1, Q3 values were given as descriptive statistics. Spearman Rank Correlation Analysis was used for correlation analysis, Man Whitney U test was used for pairwise group comparisons, and Kruskal Wallis $\mathrm{H}$ test and Bonferroni correction were used for comparisons of more than two groups.

\section{RESULTS}

A total of 810 people were reached within the scope of the study. Inattentive and incorrectly filled forms were detected and excluded by the control question and analyzes were made on a total of 720 forms. While $20 \%$ of the participants in the study are male, $80.0 \%$ are female. The mean age is $21.2 \pm 1.47$ and the median age is 21 years. While 33 people from the lowest participating OHS department attended, 249 people from the highest participating HM department at tended. Also, sufficient participants were reached from each grade. Detailed information is given in Table 2 .

Participants were asked which sources and how often they used to get information about COVID-19. Frequencies of usage are given in Table 3 . The most used source was found respectively web search with $74.0 \%$ (533), television with 63.3\% (456) and Instagram with 52.9\% (381). The least used platform was found as Facebook with $83.5 \%$ (601). It is noteworthy that scientific articles and healthcare professionals are mostly not consulted. The participants were asked why they followed the sources; 64.7\% (466) because of reliability, 65.8\% (474) easily accessibility, 65.4\% (471) sharing the information quickly and $4.3 \%$ (31) compulsory.

The knowledge of the participants towards common thoughts was given in Table 4. The statement that was most correct marked with $97.5 \%$ is the thought about symptoms. When other statements were examined, it was seen that the importance of handwashing, clothes disinfection and social distance are well understood. Also, a great majority of the participants stated that the statement virus protection is not possible (90.9\%) is wrong, and the statement that every age group is at risk (90.0\%) is correct. It was determined that the participants generally did not have clear ideas in their thoughts on the use of antibiotics, pet contamination and the effect of hot humid air on transmitting the virus.

The median value of the knowledge score was calculated as $8(\mathrm{Q} 1=6, \mathrm{Q} 3=10, \min =-4, \max =16)$. The $3.1 \%(22)$ of participants had a low level of knowledge, 52.2\% (376) had a

Table 3. Frequency of Participants' Use of Information Sources

\begin{tabular}{|c|c|c|c|c|c|c|}
\hline \multirow{2}{*}{ Information Sources } & \multicolumn{2}{|c|}{ Never } & \multicolumn{2}{|c|}{ Sometimes } & \multicolumn{2}{|c|}{ Always } \\
\hline & $\mathbf{n}$ & $\%$ & $\mathbf{n}$ & $\%$ & $\mathbf{n}$ & $\%$ \\
\hline Web Search & 15 & 2.1 & 172 & 23.9 & 533 & 74.0 \\
\hline Television & 25 & 3.5 & 239 & 33.2 & 456 & 63.3 \\
\hline Instagram & 119 & 16.5 & 220 & 30.6 & 381 & 52.9 \\
\hline Twitter & 298 & 41.4 & 137 & 19.0 & 285 & 39.6 \\
\hline YouTube & 297 & 41.2 & 246 & 34.2 & 177 & 24.6 \\
\hline Acquaintances & 127 & 17.6 & 382 & 53.1 & 211 & 29.3 \\
\hline Scientific Article & 277 & 38.5 & 368 & 51.1 & 75 & 10.4 \\
\hline Healthcare Professionals & 427 & 59.3 & 237 & 32.9 & 56 & 7.8 \\
\hline Facebook & 601 & 83.5 & 83 & 11.5 & 36 & 5.0 \\
\hline
\end{tabular}

* The data are listed from high to low according to usage rates 
Table 4. Knowledge Levels About Common Thoughts

\begin{tabular}{|c|c|c|c|c|c|c|}
\hline & \multicolumn{2}{|c|}{ Wrong } & \multicolumn{2}{|c|}{ NI / Unsure } & \multicolumn{2}{|c|}{ Correct } \\
\hline & $\mathbf{n}$ & $\%$ & $\mathbf{n}$ & $\%$ & $\mathbf{n}$ & $\%$ \\
\hline Clothes must be disinfected after returning home from outside to protect from COVID-19. & 12 & 1.7 & 13 & 1.8 & 695 & 96.5 \\
\hline High fever, cough, dyspnea are among the most common symptoms of COVID-19. & 10 & 1.4 & 8 & 1.1 & 702 & 97.5 \\
\hline $\begin{array}{l}\text { To protect against COVID-19, we should wash our hands frequently with soap and water for at least } \\
20 \text { seconds. }\end{array}$ & 12 & 1.7 & 8 & 1.1 & 700 & 97.2 \\
\hline To avoid COVID-19, a minimum social distance of 1.5 meters must be maintained. & 38 & 5.3 & 16 & 2.2 & 666 & 92.5 \\
\hline COVID-19 is transmitted through the respiratory tract after c & 87 & 12.1 & 96 & 13.3 & 537 & 74.6 \\
\hline COVID-19 is airborne. & 195 & 27.1 & 203 & 28.2 & 322 & 44.7 \\
\hline Pets do not & 172 & 23.9 & 309 & 42.9 & 239 & 33.2 \\
\hline COVID-19 ca & 342 & 47.5 & 279 & 38.7 & 99 & 13.7 \\
\hline Surgical masks (normal masks) can be washed and reused after being $\mathrm{u}$ & 534 & 74.2 & 118 & 16.4 & 68 & 9.4 \\
\hline Antibiotics are required for COVID-19 treatment. & 352 & 48.9 & 311 & 43.2 & 57 & 7.9 \\
\hline $\begin{array}{c}\text { To increase body resistance, healthy individuals should also take immune-bc } \\
\text { and vitamin pills as soon as possible. }\end{array}$ & 240 & 33.3 & 236 & 32.8 & 244 & 33.9 \\
\hline Washing the nose with saltwater, gargling with salt water prevents the infectiol & 289 & 40.1 & 236 & 32.8 & 195 & 27.1 \\
\hline Hot or humid weather prevents COVID-19 contamination. & 296 & 41.1 & 264 & 36.7 & 160 & 22.2 \\
\hline Taking a shower with hot water kills COVID-19. & 272 & 37.8 & 345 & 47.9 & 103 & 14.3 \\
\hline COVID-1 & 529 & 73.5 & 91 & 12.6 & 100 & 13.9 \\
\hline The primary risk group for COVID-19 is 65 yea & 650 & 90.3 & 28 & 3.9 & 42 & 5.83 \\
\hline It is not possible to be protected from the virus. & 655 & 91.0 & 50 & 6.9 & 15 & 2.1 \\
\hline
\end{tabular}

* The data was given downwards according to the number of times the correct option is marked

Table 5. Comparison of Knowledge Score According to the Frequency of the Following Information from Various Sources

\begin{tabular}{|c|c|c|c|c|c|c|c|c|c|}
\hline & \multicolumn{6}{|c|}{ Follow Up Frequency } & \multirow{3}{*}{$\mathbf{H}$} & \multirow{3}{*}{ df } & \multirow{3}{*}{$\mathbf{P}^{*}$} \\
\hline & \multicolumn{2}{|c|}{ Never $^{1}$} & \multicolumn{2}{|c|}{ Sometimes $^{2}$} & \multicolumn{2}{|c|}{ Always $^{3}$} & & & \\
\hline & $\mathbf{n}$ & MR & $\mathrm{n}$ & MR & $\mathbf{n}$ & MR & & & \\
\hline Scientific Articles & 277 & 362.98 & 368 & 343.50 & 75 & 434.74 & 12.167 & 2 & $0.002^{1-3.2-3}$ \\
\hline Acquaintances & 127 & 410.25 & 382 & 366.51 & 211 & 319.68 & 15.863 & 2 & $0.000^{1-3.2-3}$ \\
\hline YouTube & 297 & 393.33 & 246 & 363.87 & 177 & 300.74 & 22.287 & 2 & $0.000^{1-3.2-3}$ \\
\hline
\end{tabular}

* Kruskal Wallis Test Bonferroni Correction $(\mathrm{p}=0.05 / 3=0.016)$

Table 6. Descriptive Statistics of the DASS 21 Scale

\begin{tabular}{|c|c|c|c|c|c|c|}
\hline Subdimensions & & Normal & Mild & Middle & Severe & Extreme \\
\hline \multirow{2}{*}{ Depression } & $\mathrm{n}$ & 453 & 79 & 110 & 35 & 43 \\
\hline & $\%$ & 62.8 & 11.0 & 15.3 & 4.9 & 6.0 \\
\hline \multirow{2}{*}{ Anxiety } & $\mathrm{n}$ & 482 & 43 & 106 & 34 & 55 \\
\hline & $\%$ & 66.9 & 6.1 & 14.7 & 4.7 & 7.6 \\
\hline \multirow{2}{*}{ Stress } & $\mathrm{n}$ & 570 & 39 & 56 & 36 & 19 \\
\hline & $\%$ & 79.2 & 5.4 & 7.8 & 5.0 & 2.6 \\
\hline Subdimension Score & & Median & Min. & Max. & $\mathbf{Q 1}$ & Q3 \\
\hline Depression & & 5 & 0 & 42 & 2 & 14 \\
\hline Anxiety & & 4 & 0 & 42 & 2 & 10 \\
\hline Stress & & 6 & 0 & 42 & 2 & 14 \\
\hline
\end{tabular}

medium level of knowledge and 44.7\% (322) had a high level of knowledge.

The knowledge score of the participants who always obtain information from their acquaintances was significantly lower than those who sometimes obtain $(U=39.05 \mathrm{p}=0.03)$ and never $(\mathrm{U}=67.07 \mathrm{p}=0.00)$. The knowledge score of participants who constantly obtain information from scientific articles was significantly higher than who sometimes obtain $(\mathrm{U}=-82.69 \mathrm{p}$ $=0.00)$ and never $(\mathrm{U}=-67.02 \mathrm{p}=0.01)$ (Table 5). There was no significant difference in other information sources.

The median values of the participants in each of the dimensions of the DASS 21 scale were evaluated according to Table 1. It was found that the stress level of $79.2 \%$ of the participants was normal, $7.6 \%$ had extreme anxiety, and $15.3 \%$ had middle depression. Descriptive data are shown in Table 6.
The $11.8 \%$ (85) of participants stated that they had acquaintances diagnosed COVID-19 and 88.2\% (635) did not have. The anxiety, stress, and depression levels of participants who had a COVID-19 diagnosed acquaintances, were significantly higher than those who did not (Table 7).

Negative significant correlation found between knowledge score and stress $(r=-0.13 p=0.00)$, anxiety $(r=-0.10 p=0.01)$ and depression $(\mathrm{r}=-0.07 \mathrm{p}=0.05)$.

\section{DISCUSSION}

In this study conducted in the early phase of the COVID-19 Pandemic, it was aimed to determine how often university students use various information sources to get information about COVID-19, their level of knowledge about COVID-19, 
Table 7. Comparison of DASS-21 Scale Scores According to Having a COVID-19 Diagnosed Acquaintances

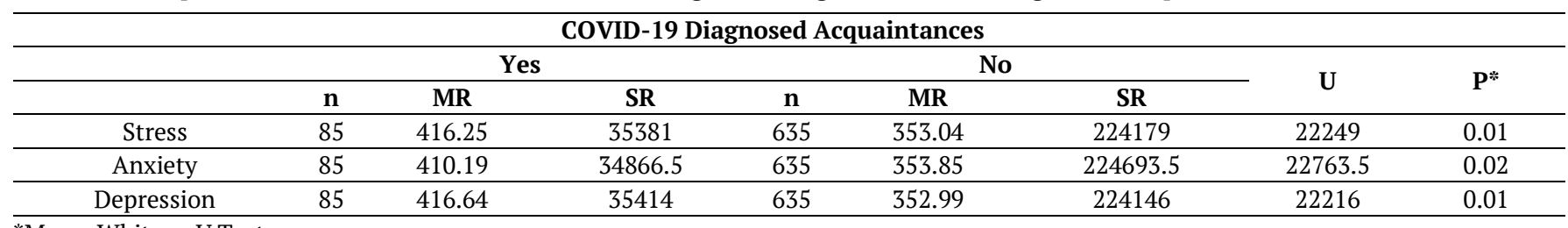

*Mann-Whitney U Test

and their levels of stress, anxiety and depression. For this purpose, an online questionnaire was applied to the students and it was determined that the students mostly used web search, followed by television and social media for information purposes. It was found that their knowledge levels were high and their levels of depression, anxiety and stress were relatively low.

The students participating in our study mostly use web search (74.0\%), television (63.3\%) and social media (Instagram: \%52.9; Twitter: \%39.6; YouTube: \%24.6; Facebook: \%5.0), respectively, to obtain information about the COVID-19. Similar to our finding, in a study investigating the media impact on university students during the SARS epidemic in Canada, when asked where they obtained information about SARS, $89.0 \%$ stated that they obtained information from the internet and 88.0\% from television (Bergeron and Sanchez, 2005). In another similar study, during the COVID-19 pandemic in Jordan, students most frequently use web search (\%66.1), television (\%59.6), social media (\%59.3), medical doctors (\%44.4) and scientific journals (\%30.0) as sources of information. The most common source of information for social media platforms was Facebook (\%59.2), followed by Instagram (\%18.4), WhatsApp (\%17.5) and Twitter (\%13.6) (Sallam et al., 2020).

Nowadays, with the development of technology, access to information has become easier and faster. In our study, participants stated that they followed the sources from which they obtained information because of their reliability, being easily accessible and sharing information quickly. In another study, the individuals participating in the study showed television as a source of obtaining health information in terms of being easily accessible and meeting the information needs easily (Koçak and Bulduklu, 2010). The easy accessibility of information sources in obtaining health information is one of the reasons why individuals are preferred.

When the knowledge of the participants towards common thoughts was examined, it was determined that $44.7 \%$ (322) were in the high level of knowledge group, $52.2 \%$ in the medium level of knowledge group and 3.1\% in the low level of knowledge group. In a COVID-19 study conducted with 1540 students in Jordan, the highest average knowledge score was found among students in health schools (Sallam et al., 2020). In similar studies conducted with medical students in Iran, Jordan and India, it was found that the students' level of knowledge was high (Modi et al., 2020; Olaimat et al., 2020; Taghrir et al., 2020). These results are in line with the results obtained in our study. The high level of health literacy of students studying in the field of Health Sciences can be explained as the reason for this situation (Şahinöz et al., 2018).

It is thought that the reason for the confusion in some of the questions asked in our study is the speculation spread through social media and word of mouth. Although there is no significant relationship between the follow-up frequency of social media tools other than YouTube and the level of knowledge, it has been concluded that the knowledge level of those who follow YouTube frequently for information purposes is significantly lower. It is important that YouTube is one of the two most used social media platforms to get information about COVID-19 (Cinelli et al., 2020). In the context of COVID-19, Li et al. (2020) analyzed the most viewed coronavirus YouTube videos and found that more than $25 \%$ of the top videos contained misleading information, with a total of 62 million views worldwide. Similarly, the knowledge level of the participants who frequently obtained information from their acquaintances was found to be significantly low, while the knowledge level of the participants who frequently used scientific articles was significantly higher. Roozenbeek et al. (2020) stated that high trust in scientists prevents the spread of false information. Also, it is known that individuals who rely on science and scientists have a higher potential to act in accordance with recommended guidelines (Plohl and Musil, 2021).

As pandemic prevention face to face education in universities in Turkey has been suspended at the time of execution of this study. Therefore, the individuals participating in the study suddenly found themselves in the middle of a serious situation. However, contrary to expectations, it was concluded that the psychological states of the individuals participating in the study were generally normal. A similar result was reached in a similar study (Cao et al., 2020).

In some studies, conducted in health-related programs, students' anxiety levels were found to be lower. Among the possible reasons for this situation, the most striking one was presented in a study conducted during the SARS epidemic, in which the anxiety levels of students studying medicine were lower than other students. According to the study, the reason for the low anxiety levels of medical students is that they have more information about the diagnosis, treatment, complications, and risk of infection. Therefore, in the study, it was concluded that knowledge of the disease can reduce an individual's fear and anxiety (Wong et al., 2004). In parallel with the results of our study, many studies conducted on students found a negative relationship between COVID-19 knowledge level and anxiety (Ardan et al., 2020; Sallam et al., 2020; Shigemura et al., 2020).

Another factor affecting the level of anxiety is thought to be risk perception. In a study conducted on university students during the SARS epidemic in Canada, it was mentioned that young individuals have a lower-risk perception compared to older individuals, and the likelihood of their anxiety levels was low (Bergeron and Sanchez, 2005). Also, living with parents 
has a significant effect on anxiety, such that students who live alone are more anxious. It is thought that the fact that the students in our sample are in their hometown and with their parents is one of the reasons that reduce their anxiety (Cao et al., 2020; Husky et al., 2020). In conclusion, it is thought that the reasons for the normal anxiety levels of the students in our study are low-risk perception, high level of knowledge and living with their family.

In some studies, contrary to these results, the anxiety levels of health students were found to be high. It was understood that this anxiety situation stems from the fact that medical and nursing students encounter infected patients due to applications and hospital visits and therefore they see themselves at higher risk than other groups of the society (Wong et al., 2004, 2007). The fact that the student group included in our study was not present in health facilities due to COVID-19 measures is thought to be the main reason why this effect was not reflected in our study.

On the other hand, students' anxiety levels may have resulted from increasing distances between people due to quarantine. It is known that in the absence of interpersonal communication, the likelihood of occurrence and worsening of anxiety disorders is higher (Kmietowicz, 2020; Xiao, 2020). Measures were taken, such as quarantine, were still new at the time we conducted the study, and therefore it was thought that this effect did not affect our study group.

In another study examining the factors affecting the anxiety levels of university students during the COVID-19 pandemic period, it was found that having an acquaintance diagnosed with COVID-19 increased the anxiety level (Cao et al., 2020). In addition, Ardan et al. (2020) stated that individuals living with people with symptoms of illness have higher anxiety levels. These results are similar to the findings of our study.

\section{CONCLUSION}

As a result of the study, it was found that the participants' levels of knowledge about COVID- 19 were high and their depression, anxiety and stress levels were generally normal. In addition, concerning these levels, it has been determined that as the level of knowledge of COVID-19 increases, depression, anxiety and stress levels decrease. Contrary to this result, having an acquaintance diagnosed with COVID-19 increases these levels. While it was determined that due to its easy accessibility the participants frequently use web searches, television and social media to get information, it was determined that those who preferred scientific articles had a higher level of knowledge.

Therefore, reliable and proven sources of information should always be used to obtain information and the use of these sources should be encouraged by the authorities. Particular care should be taken when consuming content on YouTube. Informative activities for young people can be used to convey accurate information through these platforms. It should not be forgotten that in addition to internet-based tools within the scope of information activities, television still has a high rate of followers among young people.
Author contributions: All co-authors have involved in all stages of this study while preparing the final version. They all agree with the results and conclusions.

Funding: No external funding is received for this article.

Declaration of interest: The authors declare that they have no competing interests.

Ethics approval: The study is approved by the Scientific Research and Publication Ethics Committee of Gumushane University, Turkey.

Availability of data and materials: All data generated or analyzed during this study are available for sharing when appropriate request is directed to corresponding author.

\section{REFERENCES}

Ali, A., Siddiqui, A. A., Arshad, M. S., Iqbal, F. and Arif, T.B. (2021). Effects of COVID-19 pandemic and lockdown on lifestyle and mental health of students: A retrospective study from Karachi, Pakistan. Annales MedicoPsychologiques. https://doi.org/10.1016/j.amp.2021.02.004

Al-Motlaq, M. A. (2021). “There is no corona; It's a conspiracy": Addressing the perceptions of people about COVID-19 through the narrative of their comments on social media. Journal of Consumer Health on the Internet, 25(1), 65-76. https://doi.org/10.1080/15398285.2020. 1867412

Ardan, M., Rahman, F. F. and Geroda, G. B. (2020). The influence of physical distance to student anxiety on COVID-19, Indonesia. Journal of Critical Reviews, 7(17), 1126-1132. https://doi.org/10.31838/jcr.07.17.141

Ball-Rokeach, S. J. and DeFleur, M. L. (1976). A dependency model of mass-media effects. Communication Research, 3(1), 3-21. https://doi.org/10.1177/009365027600300101

Bao, Y., Sun, Y., Meng, S., Shi, J. and Lu, L. (2020). 2019-nCoV epidemic: address mental health care to empower society. The Lancet, 395(10224), e37-e38. https://doi.org/10.1016/ S0140-6736(20)30309-3

Bergeron, S. L. and Sanchez, A. L. (2005). Media effects on students during SARS outbreak. Emerging Infectious Diseases, 11(5), 732-734. https://doi.org/10.3201/ eid1105.040512

Boberg, S., Quandt, T., Schatto-Eckrodt, T. and Frischlich, L. (2020). Pandemic populism: Facebook pages of alternative news media and the corona crisis-A computational content analysis. Available at: http://arxiv.org/pdf/2004.02566v3

Brown, T. A., Chorpita, B. F., Korotitsch, W. and Barlow, D. H. (1997). Psychometric properties of the Depression Anxiety Stress Scales (DASS) in clinical samples. Behaviour Research and Therapy, 35(1), 79-89. https://doi.org/10.1016/s00057967(96)00068-X

Bulduklu, Y. (2010). Televizyonda yayınlanan sağlı programları ve izleyicileri [Health programs and their audiences broadcast on television]. Selçuk Üniversitesi Sosyal Bilimler Enstitüsü Dergisi, 24, 75-85. 
Cao, W., Fang, Z., Hou, G., Han, M., Xu, X. and Dong, J., et al. (2020). The psychological impact of the COVID-19 epidemic on college students in China. Psychiatry Research, 287, 112934. https://doi.org/10.1016/j.psychres.2020. 112934

Chen, Q., Liang, M., Li, Y., Guo, J., Fei, D., Wang, L., et al. (2020). Mental health care for medical staff in China during the COVID-19 outbreak. The Lancet Psychiatry, 7(4), e15e16. https://doi.org/10.1016/S2215-0366(20)30078-X

Cinelli, M., Quattrociocchi, W., Galeazzi, A., Valensise, C. M., Brugnoli, E., Schmidt, A. L., et al. (2020). The COVID-19 social media infodemic. Scientific Reports, 10(1), 16598. https://doi.org/10.1038/s41598-020-73510-5

CoHE (2020). Koronavirüs (COVID-19) bilgilendirme notu. Available at: https://www.yok.gov.tr/Sayfalar/Haberler/ 2020/coronavirus_bilgilendirme_1.aspx [Accessed: 20 May 2020].

Drissi, N., Alhmoudi, A., Al Nuaimi, H., Alkhyeli, M., Alsalami, S. and Ouhbi, S. (2020). Investigating the impact of COVID19 lockdown on the psychological health of university students and their attitudes toward mobile mental health solutions: Two-part questionnaire study. JMIR Formative Research, 4(10), e19876. https://doi.org/10.2196/19876

Evans, S., Alkan, E., Bhangoo, J. K., Tenenbaum, H. and NgKnight, T. (2021). Effects of the COVID-19 lockdown on mental health, wellbeing, sleep, and alcohol use in a UK student sample. Psychiatry Research, 298, 113819. https://doi.org/10.1016/j.psychres.2021.113819

Gao, J., Zheng, P., Jia, Y., Chen, H., Mao, Y., Chen, S., et al. (2020). Mental health problems and social media exposure during COVID-19 outbreak. PloS One, 15(4), e0231924. https://doi.org/10.1371/journal.pone.0231924

González-Padilla, D. A. and Tortolero-Blanco, L. (2020). Social media influence in the COVID-19 Pandemic. International Braz J Urol: Official Journal of the Brazilian Society of Urology, 46(suppl.1), 120-124. https://doi.org/10.1590/S16775538.IBJU.2020.S121

Hall, R. C. W., Hall, R. C. W. and Chapman, M. J. (2008). The 1995 Kikwit Ebola outbreak: lessons hospitals and physicians can apply to future viral epidemics. General Hospital Psychiatry, 30(5), 446-452. https://doi.org/10.1016 /j.genhosppsych.2008.05.003

Hossain, M. M., Tasnim, S., Sultana, A., Faizah, F., Mazumder, H., Zou, L., et al. (2020). Epidemiology of mental health problems in COVID-19: A review. F1000Research, 9, 636. https://doi.org/10.12688/f1000research.24457.1

Huang, Y. and Zhao, N. (2020). Generalized anxiety disorder, depressive symptoms and sleep quality during COVID-19 outbreak in China: A web-based cross-sectional survey. Psychiatry Research, 288, 112954. https://doi.org/10.1016/ j.psychres.2020.112954

Husky, M. M., Kovess-Masfety, V. and Swendsen, J. D. (2020). Stress and anxiety among university students in France during COVID-19 mandatory confinement. Comprehensive Psychiatry, 102, 152191. https://doi.org/10.1016/ j.comppsych.2020.152191
Islam, M. S., Sarkar, T., Khan, S. H., Mostofa Kamal, A.-H., Hasan, S. M. M., Kabir, A., et al. (2020). COVID-19-related infodemic and its impact on public health: A global social media analysis. The American Journal of Tropical Medicine and Hygiene, 103(4), 1621-1629. https://doi.org/10.4269/ ajtmh.20-0812

Kecojevic, A., Basch, C. H., Sullivan, M. and Davi, N. K. (2020). The impact of the COVID-19 epidemic on mental health of undergraduate students in New Jersey, cross-sectional study. PloS One, 15(9), e0239696. https://doi.org/10.1371/ journal.pone.0239696

Kmietowicz, Z. (2020). Rules on isolation rooms for suspected COVID-19 cases in GP surgeries to be relaxed. Bmj, 368, m707. https://doi.org/10.1136/bmj.m707

Koçak, A. and Bulduklu, Y. (2010). Sağlık iletişimi: Yaşlıların televizyonda yayınlanan sağlık programlarını izleme motivasyonları [Health communication: Older people's motivations to watch televised health programs]. Selçuk İletişim, 6(3), 5-17.

Kumar, A. and Nayar, K.R. (2021). COVID 19 and its mental health consequences. Journal of Mental Health (Abingdon, England), 30(1), 1-2. https://doi.org/10.1080/09638237. 2020.1757052

Li, H. O. Y., Bailey, A., Huynh, D. and Chan, J. (2020). YouTube as a source of information on COVID-19: A pandemic of misinformation? BMJ Global Health, 5(5). https://doi.org/ 10.1136/bmigh-2020-002604

Liu, S., Yang, L., Zhang, C., Xiang, Y.-T., Liu, Z., Hu, S., et al. (2020). Online mental health services in China during the COVID-19 outbreak. The Lancet Psychiatry, 7(4), e17-e18. https://doi.org/10.1016/S2215-0366(20)30077-8

Modi, P. D., Nair, G., Uppe, A., Modi, J., Tuppekar, B., Gharpure, A. S., et al. (2020). COVID-19 awareness among healthcare students and professionals in Mumbai Metropolitan Region: A questionnaire-based survey. Cureus, 12(4), e7514. https://doi.org/10.7759/cureus.7514

Odriozola-González, P., Planchuelo-Gómez, Á., Irurtia, M. J. and Luis-García, R. de (2020). Psychological effects of the COVID-19 outbreak and lockdown among students and workers of a Spanish university. Psychiatry Research, 290, 113108. https://doi.org/10.1016/j.psychres.2020.113108

Ofcom. (2020). Half of UK adults exposed to false claims about coronavirus. Available at: https://www.ofcom.org.uk/ research-and-data/tv-radio-and-ondemand/news-media/ coronavirus-news-consumption-attitudes-behaviour [Accessed: 25 April 2021].

Olaimat, A. N., Aolymat, I., Shahbaz, H. M. and Holley, R. A. (2020). Knowledge and information sources about COVID19 among university students in Jordan: A cross-sectional study. Frontiers in Public Health, 8, 254. https://doi.org/ 10.3389/fpubh.2020.00254

Padrón, I., Fraga, I., Vieitez, L., Montes, C. and Romero, E. (2021). A study on the psychological wound of COVID-19 in university students. Frontiers in Psychology, 12, 589927. https://doi.org/10.3389/fpsyg.2021.589927 
Plohl, N. and Musil, B. (2021). Modeling compliance with COVID-19 prevention guidelines: The critical role of trust in science. Psychology, Health \& Medicine, 26(1), 1-12. https://doi.org/10.1080/13548506.2020.1772988

Roozenbeek, J., Schneider, C. R., Dryhurst, S., Kerr, J., Freeman, A. L. J., Recchia, G., et al. (2020). Susceptibility to misinformation about COVID-19 around the world. Royal Society Open Science, 7(10), 201199. https://doi.org/10.1098/rsos.201199

Ryu, S. and Chun, B. C. (2020). An interim review of the epidemiological characteristics of 2019 novel coronavirus. Epidemiology and Health, 42, e2020006. https://doi.org/ 10.4178/epih.e2020006

Sallam, M., Dababseh, D., Yaseen, A., Al-Haidar, A., Ababneh, N. A., Bakri, F. G., et al. (2020). Conspiracy beliefs are associated with lower knowledge and higher anxiety levels regarding COVID-19 among students at the university of Jordan. International Journal of Environmental Research and Public Health, 17(14), 4915. https://doi.org/10.3390/ ijerph17144915

Shigemura, J., Ursano, R. J., Morganstein, J. C., Kurosawa, M. and Benedek, D. M. (2020). Public responses to the novel 2019 coronavirus (2019-nCoV) in Japan: Mental health consequences and target populations. Psychiatry and Clinical Neurosciences, 74(4), 281-282. https://doi.org/ 10.1111/pcn.12988

Şahinöz, T., Şahinöz, S. and Kıvanç, A. (2018). Üniversite son sınıf öğrencilerinin sağlık okuryazarlığı düzeyleri üzerine karşılaştırmalı bir araştırma [A comparative study on the health literacy levels of university senior students]. Gümüşhane Üniversitesi Sağlık Bilimleri Dergisi, 7(3), 71-79.

Taghrir, M. H., Borazjani, R. and Shiraly, R. (2020). COVID-19 and Iranian medical students; A survey on their relatedknowledge, preventive behaviors and risk perception. Archives of Iranian Medicine, 23(4), 249-254. https://doi.org/10.34172/aim.2020.06

TURKSTAT (2019). Hanehalkı bilişim teknolojileri kullanım araştırması [Household ICT usage survey].

Venegas-Vera, A. V., Colbert, G. B. and Lerma, E. V. (2020). Positive and negative impact of social media in the COVID19 era. Reviews in Cardiovascular Medicine, 21(4), 561-564. https://doi.org/10.31083/j.rcm.2020.04.195
Vindegaard, N. and Benros, M. E. (2020). COVID-19 pandemic and mental health consequences: Systematic review of the current evidence. Brain, Behavior, and Immunity, 89, 531542. https://doi.org/10.1016/j.bbi.2020.05.048

Wang, C., Pan, R., Wan, X., Tan, Y., Xu, L., McIntyre, R. S., et al. (2020). A longitudinal study on the mental health of general population during the COVID-19 epidemic in China. Brain, Behavior, and Immunity, 87, 40-48. https://doi.org/10.1016/j.bbi.2020.04.028

Wong, J. G. W. S., Cheung, E. P. T., Cheung, V., Cheung, C., Chan, M. T. Y., Chua, S. E., et al. (2004). Psychological responses to the SARS outbreak in healthcare students in Hong Kong. Medical Teacher, 26(7), 657-659. https://doi.org/10.1080/01421590400006572

Wong, T. W., Gao, Y. and Tam, W. W. S. (2007). Anxiety among university students during the SARS epidemic in Hong Kong. Stress and Health, 23(1), 31-35. https://doi.org/10.1002/smi.1116

Xiang, Y.-T., Yang, Y., Li, W., Zhang, L., Zhang, Q., Cheung, T., et al. (2020). Timely mental health care for the 2019 novel coronavirus outbreak is urgently needed. The Lancet Psychiatry, 7(3), 228-229. https://doi.org/10.1016/S22150366(20)30046-8

Xiao, C. (2020). A novel approach of consultation on 2019 novel coronavirus (COVID-19)-related psychological and mental problems: Structured letter therapy. Psychiatry Investigation, 17(2), 175-176. https://doi.org/10.30773/ pi.2020.0047

Yılmaz, Ö., Boz, H. and Arslan, A. (2017). Depresyon anksiyete stres ölçeğinin (DASS 21) Türkçe kısa formunun geçerlilikgüvenilirlik çalışması [Validity-reliability study of the Turkish short form of the depression anxiety stress scale (DASS 21)]. Finans Ekonomi ve Sosyal Araştırmalar Dergisi (FESA), 2(2), 78-91.

Zhang, J., Lu, H., Zeng, H., Zhang, S., Du, Q., Jiang, T., et al. (2020). The differential psychological distress of populations affected by the COVID-19 pandemic. Brain, Behavior, and Immunity, 87, 49-50. https://doi.org/10.1016/ j.bbi.2020.04.031 